\title{
Mitochondrial-Based Therapeutics for the Treatment of Spinal Cord Injury: Mitochondrial Biogenesis as a Potential Pharmacological Target
}

\author{
Natalie E. Scholpa and Rick G. Schnellmann \\ Department of Pharmacology and Toxicology, College of Pharmacy, University of Arizona, Tucson, Arizona (N.E.S., R.G.S.); and \\ Southern Arizona VA Health Care System, Tucson, Arizona (R.G.S.)
}

Received August 28, 2017; accepted September 20, 2017

\begin{abstract}
Spinal cord injury (SCl) is characterized by an initial trauma followed by a progressive cascade of damage referred to as secondary injury. A hallmark of secondary injury is vascular disruption leading to vasoconstriction and decreased oxygen delivery, which directly reduces the ability of mitochondria to maintain homeostasis and leads to loss of ATP-dependent cellular functions, calcium overload, excitotoxicity, and oxidative stress, further exacerbating injury. Restoration of mitochondria dysfunction during the acute phases of secondary injury after $\mathrm{SCl}$ represents a potentially effective therapeutic strategy. This review discusses the past and present pharmacological
\end{abstract}

options for the treatment of $\mathrm{SCl}$ as well as current research on mitochondria-targeted approaches. Increased antioxidant activity, inhibition of the mitochondrial permeability transition, alternate energy sources, and manipulation of mitochondrial morphology are among the strategies under investigation. Unfortunately, many of these tactics address single aspects of mitochondrial dysfunction, ultimately proving largely ineffective. Therefore, this review also examines the unexplored therapeutic efficacy of pharmacological enhancement of mitochondrial biogenesis, which has the potential to more comprehensively improve mitochondrial function after SCl.

\section{Introduction}

There are over 12,000 new cases of spinal cord injury (SCI) in the United States every year, and although active individuals at any age can fall victim, the majority of injuries take place in males younger than age 30 years (Devivo, 2012). The consequences of spinal cord trauma can range from loss of function to complete paralysis below the injury site. The lack of therapeutics capable of restoring function results in this patient population being dependent on healthcare support for the remainder of their lifetime. Nevertheless, with advancements in medical and surgical care, survivors of SCI generally live long lives after injury, with life expectancy correlating with SCI-induced neurologic impairment (Wyndaele and Wyndaele, 2006; Middleton et al., 2012).

This work was supported by the National Institutes of Health National Institute of General Medical Sciences [Grant R01 GM084147 (to R.G.S.)] and the Biomedical Laboratory Research and Development Program of the Department of Veterans Affairs [Grant BX000851 (to R.G.S.)].

https://doi.org/10.1124/jpet.117.244806.
Unfortunately, patients with SCI often develop progressive complications in addition to their injury, including cardiovascular disease, gastrointestinal problems, chronic pain, and depression (Myers et al., 2007). The resulting cost of care is estimated at greater than $\$ 3$ million per patient (Devivo, 2012), which places a tremendous burden on patients, caregivers, and the healthcare system in general and demonstrates the need for continued research on the development of therapeutics for individuals suffering from SCI. Furthermore, the development of more effective ways of maintaining and recovering function after SCI could allow patients greater levels of both independence and productivity, drastically improving patient outlook.

\section{SCI Pathology}

SCI occurs in two phases: primary injury and secondary injury (Fig. 1). Primary injury refers to the immediate mechanical trauma to the spinal cord, which can be caused by compression, contusion, or distension; the most common of

ABBREVIATIONS: ALC, acetyl-L-carnitine; CNS, central nervous system; CsA, cyclosporin A; ETC, electron transport chain; GSH, glutathione; LP, lipid peroxidation; MB, mitochondrial biogenesis; MP, methylprednisolone; mPTP, mitochondrial permeability transition pore; NACA, N-acetylcysteinamide; NASCIS, National Acute Spinal Cord Injury Study; NIM811, N-methyl-4-isoleucine cyclosporin; PDH, pyruvate dehydrogenase; PGC, peroxisomal proliferator $\gamma$ coactivator; ROS, reactive oxygen species; SCI, spinal cord injury; TBI, traumatic brain injury; TFAM, mitochondrial transcription factor $A$. 


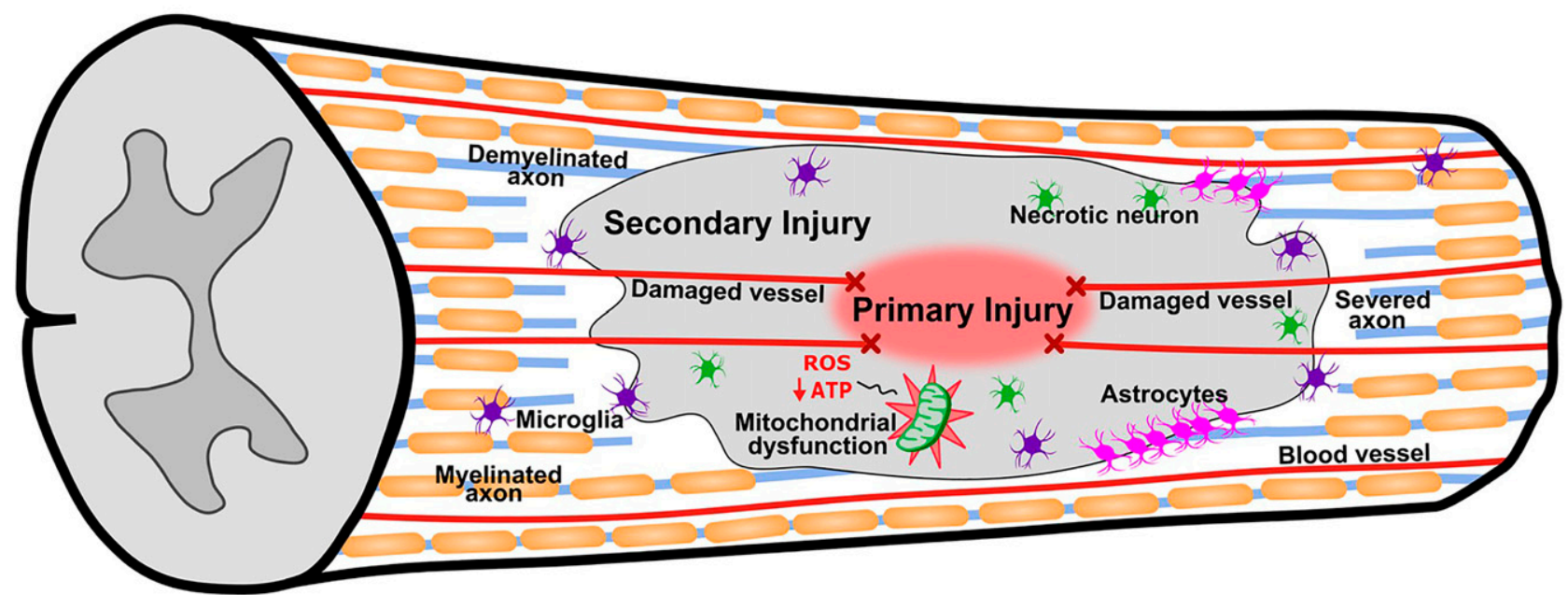

Fig. 1. SCI pathology. The extent of damage after SCI is a combination of the initial trauma and secondary injury. The primary injury induces damage to the vasculature of the spinal cord, reducing local oxygen delivery, which decreases mitochondrial function and ATP synthesis and increases ROS production. In addition to mitochondrial dysfunction, hallmarks of secondary injury after SCI include neuronal cell death, axon demyelination and severing, microglia activation, and glial scar formation.

these is contusion (Sekhon and Fehlings, 2001; Baptiste and Fehlings, 2006). Complete spinal cord transection can occur but little to no functional recovery has been observed with pharmacological intervention alone in these instances; however, combinatorial therapies involving cellular transplantation have shown some promise (Coumans et al., 2001; Fouad et al., 2005). There exists the possibility for pharmacological intervention to aid in recovery after incomplete spinal cord transection, such as that generally observed after contusion, because the remaining intact tissue has the potential for repair (Hall and Springer, 2004). For the purposes of this review, we focus on incomplete transection.

Within the first minutes to hours after injury, a secondary cascade is initiated, which can last for weeks or months and whose damaging effects are comparative to, if not greater than, that of the initial insult (Tanhoffer et al., 2007; Oyinbo, 2011). Consequences of secondary injury include progressive axon demyelination (Totoiu and Keirstead, 2005), neuronal cell death (Beattie et al., 2002; Anwar et al., 2016), microglia activation and inflammation (Qiao et al., 2010, 2015), glial scar formation (Shibuya et al., 2009), and mitochondrial dysfunction, all of which contribute to the progressive pathology. Because of the far-reaching effects of secondary injury, pharmacological therapeutics that seek to interrupt or control this stage of injury have the potential to improve neuron survival, allowing functional recovery (Hall and Sullivan, 2005; Oyinbo, 2011).

Over 25 mechanisms of secondary injury after SCI-as well as a temporal association of their occurrences, ranging from seconds (acute) to years (chronic) postinjury-have been identified (Oyinbo, 2011). For a more thorough discussion of secondary injury, see reviews by Tator and Fehlings (1991), Anderson and Hall (1993), Hall and Springer (2004), and Rowland et al. (2008). In brief, the initial primary trauma results in mechanical disruption of the spinal cord vasculature, leading to vasoconstriction and contributing to hemorrhage, edema, hypoperfusion, and ischemia (Baptiste and Fehlings, 2006; Graumann et al., 2011). Ischemia is considered a key mechanism of secondary injury, with the degree of functional loss being proportional to the degree of ischemia postinjury (Tator and Fehlings, 1991). Although angiogenesis does take place after SCI, the emerging vessels are often leaky and therefore do not allow for the necessary delivery of nutrients or removal of waste within the injured spinal cord (Kundi et al., 2013). Furthermore, the subsequent local decrease in oxygen delivery directly reduces the ability of mitochondria to maintain homeostatic function (Graumann et al., 2011; Kundi et al., 2013).

Mitochondria after SCI. Mitochondria are doublemembraned organelles that, through oxidative phosphorylation, produce the majority of ATP for the cell. The outer mitochondrial membrane is a phospholipid bilayer containing voltage-dependent anion channels that, when open, allow the passage of small molecules, including ions, ATP, and ADP (Lemasters and Holmuhamedov, 2006; McEwen et al., 2011). The more complex inner membrane, while freely permeable to oxygen, water, and carbon dioxide, contains numerous tightly controlled channels, which regulate the electron transport chain (ETC) to maintain the necessary electrochemical gradient $(\Delta \psi)$ for ATP synthesis (Saraste, 1999; Kinnally et al., 2011). Various reactive oxygen species (ROS) (e.g., superoxide anion, hydrogen peroxide, and hydroxyl radicals) can be formed when electrons leak from the ETC and combine with $\mathrm{O}_{2}$ in the mitochondrial matrix. Under control circumstances, endogenous antioxidant systems protect from ROS-induced toxicity (Candas and Li, 2014); however, disruption of the ETC under pathologic conditions can cause not only an energy deficit due to loss of ATP synthesis but also an increase in ROS production (Turrens, 2003) beyond the neutralizing capabilities of antioxidant systems.

Recently, understanding of the role of mitochondria within the central nervous system (CNS) has shifted from merely energy suppliers to essential contributors to both neural homeostasis and neurodegeneration (Dubinsky, 2005). Mitochondrial dysfunction after SCI has been suggested to be crucial for the proliferation of secondary injury and subsequent neuronal cell death (Sullivan et al., 2007). Neurons depend on stringent and efficient ATP-dependent regulation 
of various ions across the plasma membrane to maintain electrical homeostasis and to readily accommodate action potential conduction and the release/uptake of neurotransmitters. In addition, neurons have limited capacity to buffer oxidative stress (Adibhatla and Hatcher, 2010).

Given these large energy requirements and limited antioxidant defenses, neurons rely heavily on mitochondrial metabolism and ATP production and are susceptible to compromised mitochondria (Uttara et al., 2009; Moskowitz et al., 2010; Wang and Michaelis, 2010); even small mitochondrial defects can cause functional consequences and eventual pathology within the CNS (Dubinsky, 2005). Loss of mitochondrial function, such as that observed with secondary injury after SCI, results in the loss of ATP and inactivation of ATPdependent ion pumps required for regulation of ion concentrations as well as reuptake of the excitatory neurotransmitter glutamate. This dysfunction ultimately leads to excitotoxicity, calcium overload, and the eventual initiation of cell death cascades, all of which are hallmarks of SCI and further exacerbate injury in this self-propagating cycle (Choi and Rothman, 1990; Rowland et al., 2008; Oyinbo, 2011).

An early secondary event after SCI is depolarization and opening of voltage-dependent ion channels, leading to the release of neurotransmitters, including glutamate. Glutamate binds to glutamate receptors, opens corresponding ion channels, and results in accumulation of intracellular $\mathrm{Ca}^{2+}$ (Hall and Springer, 2004). Such ionic shifts can persist for days in injured tissue after SCI (Young and Koreh, 1986; Demediuk et al., 1990; LoPachin et al., 1999). Under control conditions, mitochondria can sequester and retain exogenous $\mathrm{Ca}^{2+}$ via an electrogenic carrier that facilitates transport across the inner membrane. Once $\mathrm{Ca}^{2+}$ is in the mitochondrial matrix, $\mathrm{Ca}^{2+}$ is stored in the form of inactive precipitates, which are eventually slowly released back into the cytosol (Crompton, 1999; Starkov, 2010). When $\mathrm{Ca}^{2+}$ is accumulated above a certain threshold, however, $\mathrm{Ca}^{2+}$ will trigger the opening of the mitochondrial permeability transition pore (mPTP; Fig. 2).

The opening of the mPTP results in the loss of $\Delta \psi$ leading to the cessation of ATP synthesis and has been linked to necrosis and apoptosis after brain injury, neurodegenerative disorders, and SCI (Hirsch et al., 1998; Lemasters et al., 1998; Crompton, 1999; Friberg and Wieloch, 2002; Norenberg and Rao, 2007; Bezprozvanny, 2009; Pivovarova and Andrews, 2010). In addition, opening of the pore allows molecules and water into the mitochondria, causing the matrix to swell as it equilibrates with the cytosol and enlarging the inner membrane until the outer membrane ruptures, releasing accumulated $\mathrm{Ca}^{2+}, \mathrm{ROS}$, and proapoptotic proteins (e.g., cytochrome $c$ ) into the cytosol, and promoting cell death (Sesso et al., 2004; McEwen et al., 2011). Importantly, Sullivan et al. (2004a) demonstrated that spinal cord mitochondria have a reduced $\mathrm{Ca}^{2+}$ threshold for opening of the mPTP than that of mitochondria isolated from the brain, further indicating the necessity of restoring mitochondrial homeostasis after SCI.

A consequence of the persistent ion shift during secondary injury is increased ROS. ROS are normal byproducts of mitochondrial function, but $\mathrm{Ca}^{2+}$ overload increases production in the CNS (Lewén and Hillered, 1998; Sullivan et al., 2004b). SCI induces a detrimental self-proliferating cycle of increased ROS production, leading to oxidative damage and

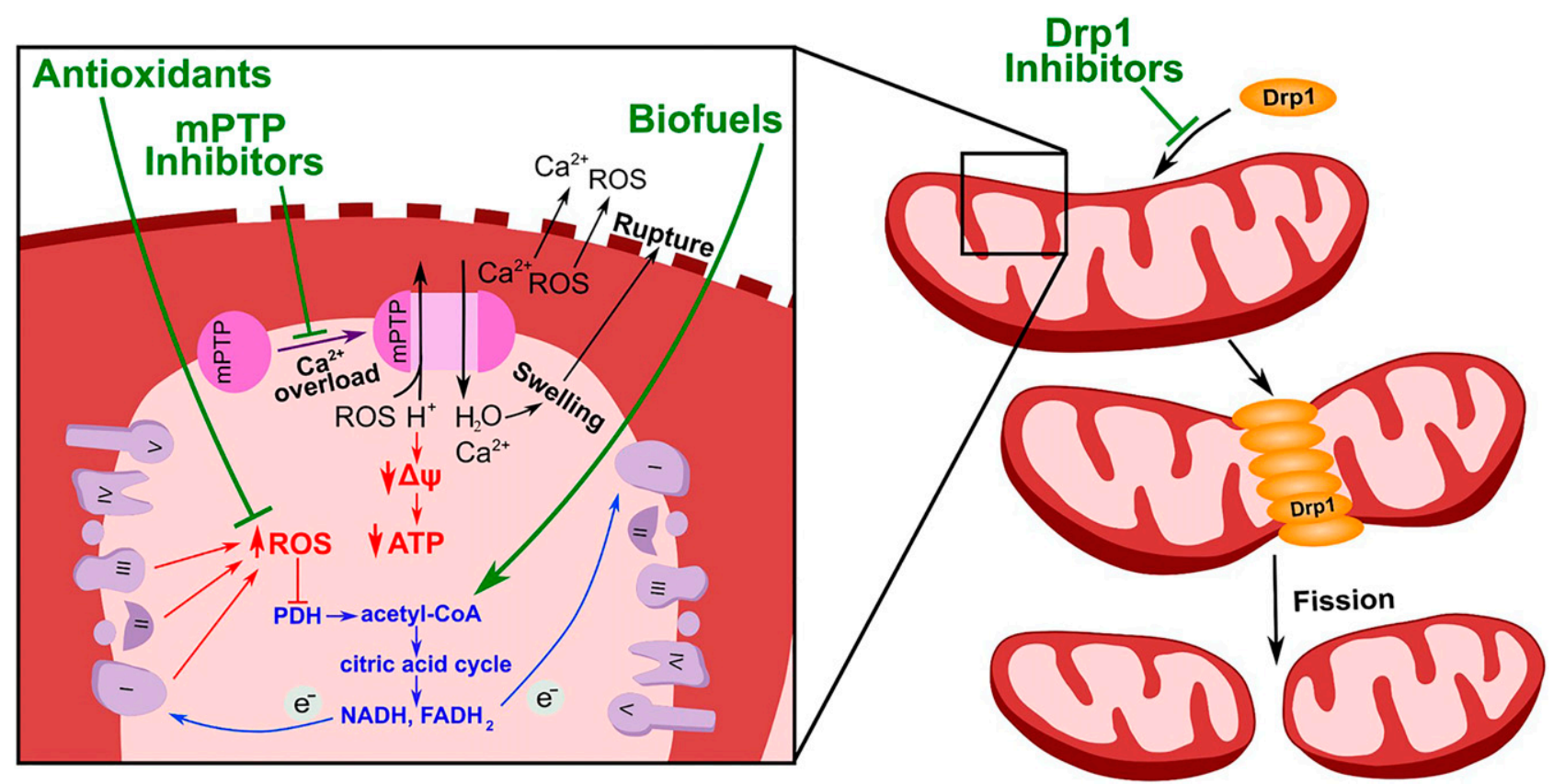

Fig. 2. Mechanisms to target mitochondrial homeostasis for the treatment of SCI. After SCI, cellular $\mathrm{Ca}^{2+}$ influx results in the opening of the mPTP and loss of the electrochemical gradient $(\Delta \psi)$ necessary for ATP synthesis. mPTP opening also allows water and other molecules to move into the mitochondrial matrix, causing the matrix to swell and the outer membrane to rupture, releasing $\mathrm{ROS}^{2} \mathrm{Ca}^{2+}$, and proapoptotic proteins such as cytochrome $c$ into the cytosol. CsA and its analog NIM811 act by binding to and inhibiting opening of the mPTP, preventing mitochondrial dysfunction. Biofuels such as ALC serve as alternate energy sources, allowing the citric acid cycle to continue despite the oxidative damage-induced inactivation of PDH. Antioxidants neutralize the activity of ROS through various mechanisms, contributing to enhanced mitochondrial function. Evidence indicates that mitochondrial fission is initiated shortly after injury, contributing to SCI-induced neuronal apoptosis. Compounds such as Mdivi-1, which inhibit Drp1, a major protein in mammalian mitochondrial fission, thereby prevent fission and decreased mitochondrial function. $\mathrm{e}^{-}$, electron; $\mathrm{H}^{+}$, hydrogen ion; $\mathrm{H}_{2} \mathrm{O}$, water. 
additional ROS production, until pathologic levels are eventually reached. A particularly detrimental consequence of ROS is the formation of the powerful oxidant peroxynitrite (Violi et al., 1999). Development of peroxynitrite is increased after injury due to the increased concentration of superoxide and $\mathrm{Ca}^{2+}$-induced activation of nitric oxide synthase within the mitochondria (Bringold et al., 2000). Peroxynitrite can also trigger cell membrane lipid peroxidation (LP), protein carbonylation, and tyrosine nitration, damaging and impairing mitochondria and altering neuronal function after SCI (Violi et al., 1999; Sullivan et al., 2007; Hall et al., 2016).

LP results in additional free radicals, which propagate damage (Hall et al., 2016). LP can occur in blood vessels and neurons, which not only impairs neuronal and vascular integrity but also promotes ischemia and further contributes to secondary neuronal injury (Hall and Springer, 2004). Targeting reestablishment of mitochondrial homeostasis prior to damaging levels of ROS formation could potentially attenuate secondary injury after SCI. Temporal analysis revealed altered mitochondrial morphology beginning 2 hours after SCI, with increases in markers of oxidative damage beginning approximately 8 hours after injury and continuing until at least 24 hours after SCI (Sullivan et al., 2007; Jia et al., 2016). These data reveal the potential existence of an 8-hour window for therapeutic intervention to regain mitochondrial homeostasis after SCI.

\section{Current Treatment of SCI: The National Acute Spinal Cord Injury Study and Methylprednisolone}

Based on their ability to reduce peritumoral brain edema in patients with tumors, glucocorticoid steroids, including methylprednisolone (MP), were primarily used to treat SCI in 1960 s and 1970s, with the assumption that they would also reduce post-SCI edema (Reulen et al., 1973). The first National Acute Spinal Cord Injury Study (NASCIS I), a clinical trial performed in the early 1980 s, showed that the benefits of steroid treatment were limited, if not nonexistent. Furthermore, increased risk of infection, a known side effect of glucocorticoids, was observed with high-dose treatments (Bracken et al., 1984, 1985). Based on these findings, a general consensus within the neuroscience community was reached, which concluded that the use of steroids after SCI was simultaneously risky and unhelpful (Hall and Springer, 2004).

NASCIS II took place in the 1990s following enhanced understanding of the mechanism of post-SCI LP (Hall and Braughler, 1981; Anderson et al., 1982; Young and Flamm, 1982; Hall et al., 1984). The findings from this study revealed that patients functionally benefited from treatment with highdose MP (30 mg/kg i.v. bolus plus hourly $5.4 \mathrm{mg} / \mathrm{kg}$ for 23 hours), presumably via LP inhibition resulting in decreased injury progression, as long as dosing was initiated within 8 hours postinjury (Bracken et al., 1990, 1992; Bracken and Holford, 1993). Based on these data, the standard of care for the treatment of SCI became the systemic administration of MP for 24 hours (Rabchevsky et al., 2011). In the late 1990s, the NASCIS III clinical trial evaluated MP using the same dosing regimen used in NASCIS II, extended MP doses (48 hours), and a third treatment consisting of one $30-\mathrm{mg} / \mathrm{kg}$ MP bolus followed by 48-hour administration of tirilazad, a nonglucocorticoid steroid (Braughler et al., 1988; Hall et al., 1994; Bracken et al., 1997, 1998). In general, all three treatment groups produced comparable degrees of recovery when initiated within 3 hours after SCI. When initiated between 3 and 8 hours postinjury, 48-hour MP was the most effective but also had the highest incidence of glucocorticoidrelated side effects (Bracken et al., 1997, 1998).

There are many potential side effects of high doses of MP, including an increased risk of gastrointestinal bleeding, deep vein thrombosis, pneumonia, septic shock, and delayed wound healing (Evaniew et al., 2015), which can offset the neuroprotective effects of MP and compromise functional outcome and even survival. In addition, treatment initiation past the 8-hour window can actually exacerbate injury and decrease recovery compared with no treatment (Bracken and Holford, 1993). Glucocorticoid-induced neurotoxicity has also been observed in certain neuronal populations, such as the hippocampus (Sapolsky, 1985; McIntosh and Sapolsky, 1996).

In the decade after the NASCIS trials, multiple highly critical reviews of the studies surfaced, which criticized the lack of functional assessment, the lack of placebo groups, the safety of high-dose MP, and the small effect sizes in only a subpopulation of patients (Coleman et al., 2000; Hurlbert, 2000; Short et al., 2000; Evaniew et al., 2015). In 2013, the Guidelines for the Management of Acute Cervical Spine and Spinal Cord Injuries were updated, downgrading data obtained from the NASCIS trials from class I ("well executed") to class III ("unhelpful for establishing quality") and they no longer recommend the use of MP for the treatment of acute SCI, stating that the evidence supporting beneficial effects was inconsistent and likely due to random chance (Walters et al., 2013). As such, treatment with MP after SCI is now up to the discretion of the attending physician (Rabchevsky et al., 2011).

\section{Mitochondrial-Based Treatment}

Despite promising treatments in animal models of SCI, there is currently no meaningful therapy for the treatment of SCI in humans. Secondary injury is a complex cascade of events that initiates many additional pathologies; therefore, therapeutics targeting specific downstream events after SCI may prove merely palliative and ultimately nonefficacious. Based on temporal data presented by Sullivan et al. (2007), restoration of mitochondrial function shortly after injury may be a more comprehensive approach for the treatment of SCI (McEwen et al., 2011; Rabchevsky et al., 2011).

Many pharmacological agents that have proven beneficial for the treatment of SCI in vivo affect mitochondria or mitochondrial function to some extent. For example, the antibiotic minocycline was found to have neuroprotective effects and induce behavioral and cellular recovery after SCI in rats (Wells et al., 2003; Teng et al., 2004; Sonmez et al., 2013; Aras et al., 2015; Ahmad et al., 2016). The spectrum of effects of minocycline includes mitochondrial stabilization, inhibition of the release of cytochrome $c$, and antioxidant activity (Wells et al., 2003; Casha et al., 2012; Aras et al., 2015). In addition, lithium treatment has been reported to stimulate mitochondrial respiration in human brain tissue and to enhance neuronal regeneration after SCI in vivo (Yick et al., 2004; Maurer et al., 2009). Unfortunately, however, both of these treatments proved ineffective during phase II clinical trials (Casha et al., 2012; Yang et al., 2012). Restoration of mitochondrial function after SCI remains a popular therapeutic strategy and can be targeted directly via several 
different mechanisms, including inhibition of the mPTP, the use of alternate energy sources, enhanced antioxidant activity, and altered mitochondrial morphology.

Inhibition of the mPTP. As stated previously, opening of the mPTP contributes to several pathologic events that take place during secondary injury. Therefore, targeting components of the mPTP to inhibit the mitochondrial permeability transition after SCI may have therapeutic benefits (Fig. 2). The immunosuppressant cyclosporin A (CsA) binds to and inhibits the mPTP and has been associated with enhanced mitochondrial function and decreased cell death in the CNS (Waldmeier et al., 2003; Basso et al., 2005; Kim et al., 2014). Particularly, studies have demonstrated that CsA has neuroprotective properties in models of traumatic brain injury (TBI) and stroke (Matsumoto et al., 1999; Scheff and Sullivan, 1999; Sullivan et al., 1999, 2000; Uchino et al., 2002).

Unfortunately, assessments of the neuroprotective effects of CsA after SCI have proven inconclusive and inconsistent (Ibarra et al., 1996a,b, 2003; Rabchevsky et al., 2001; McMahon et al., 2009). Differences in the efficacy of CsA between TBI and SCI may be attributed to fundamental differences in spinal cord and cortical mitochondria (Sullivan et al., 2004a). Regardless of any positive results, however, CsA is highly toxic, making it less than ideal as a therapeutic (Caramelo et al., 2004; Schenk et al., 2010; Rabchevsky et al., 2011; Szalowska et al., 2015). NIM811 ( $N$-methyl-4-isoleucine cyclosporin) is an analog of CsA that also inhibits the $\mathrm{mPTP}$, is much less toxic, and lacks immunosuppressive properties (Waldmeier et al., 2002). Very few studies have been performed regarding the therapeutic potential of NIM811 in the CNS, with even fewer investigating SCI (Waldmeier et al., 2002; McEwen et al., 2007; Ravikumar et al., 2007; Mbye et al., 2008, 2009). The data obtained from these limited studies, however, suggest that NIM811 induces neuroprotection after SCI (McEwen et al., 2007; Ravikumar et al., 2007) and strongly indicate that the therapeutic efficacy of NIM811 deserves further investigation.

Alternate Energy Sources: "Biofuels.”. After SCI, several mitochondrial enzymes are inactivated due to oxidative damage. One such example is pyruvate dehydrogenase (PDH), a critical enzyme in the generation of acetyl-CoA (McEwen et al., 2011). Acetyl-CoA is necessary for the citric acid cycle and the production of $\mathrm{NADH}$ and $\mathrm{FADH}_{2}$, electron donors for the ETC. Because of this PDH deficit, introduction of alternate energy sources ("biofuels") could potentially alleviate mitochondrial dysfunction after SCI (Fig. 2).

Acetyl-L-carnitine (ALC) is an endogenous component of the inner mitochondrial membrane that readily crosses the bloodbrain barrier and provides acetyl groups to facilitate the synthesis of acetyl-CoA, thereby bypassing the need for PDH (Pettegrew et al., 2000; McEwen et al., 2011). ALC also increases the production of glutathione (GSH), giving it a bipartite effect and further increasing its therapeutic appeal (Pettegrew et al., 2000; Karalija et al., 2012). ALC is shown to have beneficial effects for a number of neurodegenerative diseases, including Parkinson disease, Alzheimer disease, and multiple sclerosis (Puca et al., 1990; Pettegrew et al., 2000; Tomassini et al., 2004). Interestingly, Karalija et al. (2012) demonstrated that chronic ALC administration reduces neuronal degeneration after SCI in rats. Furthermore, Patel et al. (2010, 2012) found that treatment with ALC after SCI maintained mitochondrial function, improved functional recovery, and protected both white and gray matter within the spinal cord from further injury. ALC administration was also shown to reduce the number of damaged mitochondria, improve mitochondrial membrane potential, and decrease SCI-induced apoptosis in rats (Zhang et al., 2015). These studies, although few in number, suggest the potential for ALC as a therapeutic treatment of SCI.

Antioxidant Approaches. The consequences of ROS formation and oxidative damage after SCI are well characterized and were briefly discussed above. For a more comprehensive description, see a review by Hall (2011). For a more thorough review on antioxidant-based therapeutics for the treatment of SCI, see Bains and Hall (2012). Pharmacological intervention of oxidative damage after SCI (Fig. 2) can occur via several different mechanisms, both direct and indirect. Indirect mechanisms include preventing the formation of ROS and ROS scavenging; direct mechanisms include halting LP propagation or scavenging LP-induced free radicals (Hall, 2011; Bains and Hall, 2012). A short therapeutic window is one significant limitation of the aforementioned indirect mechanisms. Multiple studies have reported near instantaneous increases in ROS production after SCI (Liu et al., 1998, 2004; Bao and Liu, 2004; Xiong et al., 2007), which means that pharmacological agents would need to be administered immediately to ensure that they are able to act and interfere with the initial "burst" of free radical production that occurs after SCI (Hall, 2011; Bains and Hall, 2012; Hall et al., 2016).

$\alpha$-Tocopherol is a naturally occurring form of vitamin $\mathrm{E}$, which can scavenge lipid peroxyl radicals and has been shown to improve recovery and decrease LP after SCI (Anderson et al., 1988; Bozbuğa et al., 1998; Al Jadid et al., 2009; Morsy et al., 2010; Morsy and Bashir, 2013). Unfortunately, this process is 1:1 and the radical form of vitamin $\mathrm{E}$ is produced after scavenging, which has no antioxidant properties. Furthermore, it has been suggested that high-dose supplementation of vitamin $\mathrm{E}$, such as that which would be necessary to decrease baseline LP levels in humans (Roberts et al., 2007), can increase mortality (Miller et al., 2005) and thus should be avoided.

$N$-acetylcysteineamide (NACA), a membrane-permeable U.S. Food and Drug Administration-approved thiolcontaining variant of the GSH precursor $N$-acetylcysteine, was observed to enhance GSH content, improving mitochondrial bioenergetics and correlating with functional recovery in rat models of both TBI and SCI when administered 15-30 minutes postinjury (Pandya et al., 2014; Patel et al., 2014). Although these results are undoubtedly encouraging, additional studies must be performed to assess the therapeutic window for treatment initiation, particularly considering that $N$-acetylcysteine was previously shown to be ineffective in rats if not given within 1 hour after TBI (Xiong et al., 1999).

Spin trap molecules, such as the free radical scavengers tempol (4-hydroxy-2,2,6,6-tetramethylpiperidine- $N$-oxyl) and Neu2000 (2-hydroxy-5-[2,3,5,6-tetrafluoro-4-trifluoro-methylbenzylamino]-benzoic acid), have produced inconsistent results after SCI, in part due to their lack of targeted mitochondrial selectivity (Patel et al., 2009; Xiong et al., 2009; Springer et al., 2010; McEwen et al., 2011; Visavadiya et al., 2013). Biomolecules consisting of antioxidants covalently bonded to mitochondrial targeting compounds (e.g., triphenylphosphonium cation) have been generated to combat this limitation (Murphy, 1997, 2001; Murphy and Smith, 
2007); however, the efficacy of these compounds has not yet been tested in SCI.

Fission and Fusion. Mitochondria change form and function to meet requirements of the cell; as such, they are both highly controlled and dynamic. Alterations in the size and number of mitochondria are regulated by the coordination of fission (the division of single mitochondria into multiple daughter mitochondria) and fusion (the formation of a single mitochondrion from previously independent structures) (Scott and Youle, 2010). In physiologic conditions, mitochondria are constantly undergoing balanced fission and fusion. Because mitochondria cannot be formed de novo, fission is necessary for cell division; however, fission and fusion are also consistently observed in many nondividing cells, partially due to the necessity of replacing or removing damaged mitochondrial components. Furthermore, mutations in fission and fusion regulatory genes are associated with various pathologies, indicating the importance of normal mitochondrial dynamics (Züchner et al., 2004; Ranieri et al., 2012).

Recently, it was shown that SCI alters fission and fusion, contributing to mitochondrial dysfunction. Cao et al. (2013) observed a biphasic response in mitochondrial morphology within the first 24 hours after SCI in rats. At 3-6 hours after SCI, spinal cord neuronal mitochondrial were larger and fewer in number, correlating with increased expression of fusion proteins mitofusin Mfn1 and Mfn2 and decreased expression of the primary mammalian fission-related proteins mitochondrial fission 1 and dynamin-related protein 1 (Drp1). By 12-24 hours after injury, however, the opposite pattern was observed. Jia et al. (2016) performed a temporal analysis of mitochondrial morphology after SCI, which similarly revealed larger mitochondria and increased Mfn1 expression at early time points that peaked by 8 hours after SCI and then decreased by 24 hours, whereas Drp1 expression was diminished as early as 2 hours after injury and then gradually increased by 24 hours.

Mitochondrial fission and fusion are closely related to not only morphology but also cellular function and apoptosis, in that mitochondrial fusion is thought to inhibit apoptosis, whereas fission is thought to promote it (Jia et al., 2016). In addition, studies have indicated that spinal cord cell death is abundantly due to apoptosis after injury, as opposed to a direct effect of the trauma (Liu et al., 1997). It was observed that as spinal cord Drp1 increased within the first 24 hours after injury, mitochondrial membrane potential decreased, and cytochrome $c$ release and caspase-3 expression increased, culminating in apoptosis (Jia et al., 2016). These data indicate that fusion and fission are integral to early and late stages of acute SCI, respectively (Cao et al., 2013; Jia et al., 2016), and suggest that therapeutic intervention targeting fusion/fission prior to this switch could prove beneficial after SCI.

Mitochondrial division inhibitor-1 (Mdivi-1; Fig. 2), a selective Drp1 inhibitor, has proven beneficial in in vivo models of various CNS and non-CNS pathologies, including TBI (Wu et al., 2016), amyotrophic lateral sclerosis (Luo et al., 2013), stroke (Zhang et al., 2013; Cui et al., 2016), acute kidney injury (Tang et al., 2013), and myocardial infarction (Ding et al., 2017). Despite these data, only two studies thus far have investigated the effect of Mdivi-1 on SCI (Li et al., 2015; Liu et al., 2015). Li et al. (2015) observed that treatment with Mdivi-1 prior to SCI in rats increased ATP and mitochondrial membrane potential, and decreased caspase- 3 release and the number of apoptotic cells by 72 hours postinjury. These effects correlated with improved locomotor function in the treated group. Similarly, Liu et al. (2015) observed neuroprotective effects of Mdivi-1, both in cultured spinal cord neurons exposed to glutamate and after ischemic/reperfusion SCI in rats. Mdivi-1 treatment resulted in increased endogenous antioxidant activity, decreased ROS, and decreased cytochrome $c$ release in vitro, as well as improved locomotor function in vivo (Liu et al., 2015). Although these data are promising, one study used a pretreatment method, whereas the other began treatment at the initiation of injury; therefore, additional work is necessary to assess the therapeutic efficacy of Mdivi-1 after SCI.

\section{Mitochondrial Biogenesis}

The currently available therapeutics are not sufficient to effectively treat SCI. In fact, as of 2013, there was no recommended pharmacological intervention after injury (Walters et al., 2013). Although there have been promising preliminary studies investigating the efficacy of NACA, NIM811, Mdivi-1, and mitochondrial-targeted antioxidants, there remains a great deal of work to be done with these compounds and, as is often the case, there is no guarantee that the results observed in animals will translate to humans. Hall et al. (2016) suggested that combinatorial therapies could address the obvious deficit in treatment, as pursuing a single facet of the mitochondrial dysfunction-induced damage that occurs after SCI may not be enough to produce effective neuroprotection. An alternate method of targeting multiple aspects of mitochondrial function that has not yet been effectively explored for the treatment of SCI is pharmacological enhancement of mitochondrial biogenesis (MB).

Regulation of MB. MB is a transcriptional program that can be defined as the repair, growth, and/or division of preexisting mitochondria (Ventura-Clapier et al., 2008). This process involves an intricate network of several transcriptional pathways for both nuclear- and mitochondrial DNAencoded genes, many of which are outlined in Fig. 3. MB is governed by the "master regulator" peroxisomal proliferator $\gamma$ coactivator (PGC)-1 $\alpha$, which controls the expression of this network (Kelly and Scarpulla, 2004; Ventura-Clapier et al., 2008). PGC- $1 \alpha$ interacts with and coactivates several transcription factors, including nuclear respiratory factors 1 and 2 and peroxisome proliferator-activated receptors. This results in the transcription of nuclear-encoded subunits of the ETC, including ATP synthase $\beta$ and NADH:ubiquinone oxidoreductase subunit 1 , antioxidant proteins such as superoxide dismutase 2 , and other mitochondrial genes, including uncoupling protein 2 and mitochondrial transcription factor A (TFAM). After its transcription and translation, TFAM translocates into the mitochondrial matrix, where it stimulates mitochondrial DNA replication and the transcription of mitochondrial-encoded genes, including cytochrome $c$ oxidase subunit 1 and NADH dehydrogenase subunit 1 (VenturaClapier et al., 2008). Nuclear-encoded proteins are then transferred into the mitochondria, where nuclear- and mitochondrial-encoded subunits of the ETC are assembled.

Pharmacological agents can augment MB through interaction with the various pathways that regulate this process. For example, agonism of $\mathrm{G}$ protein-coupled serotonin (5-hydroxytryptamine) and $\beta$-adrenergic receptors can activate the 


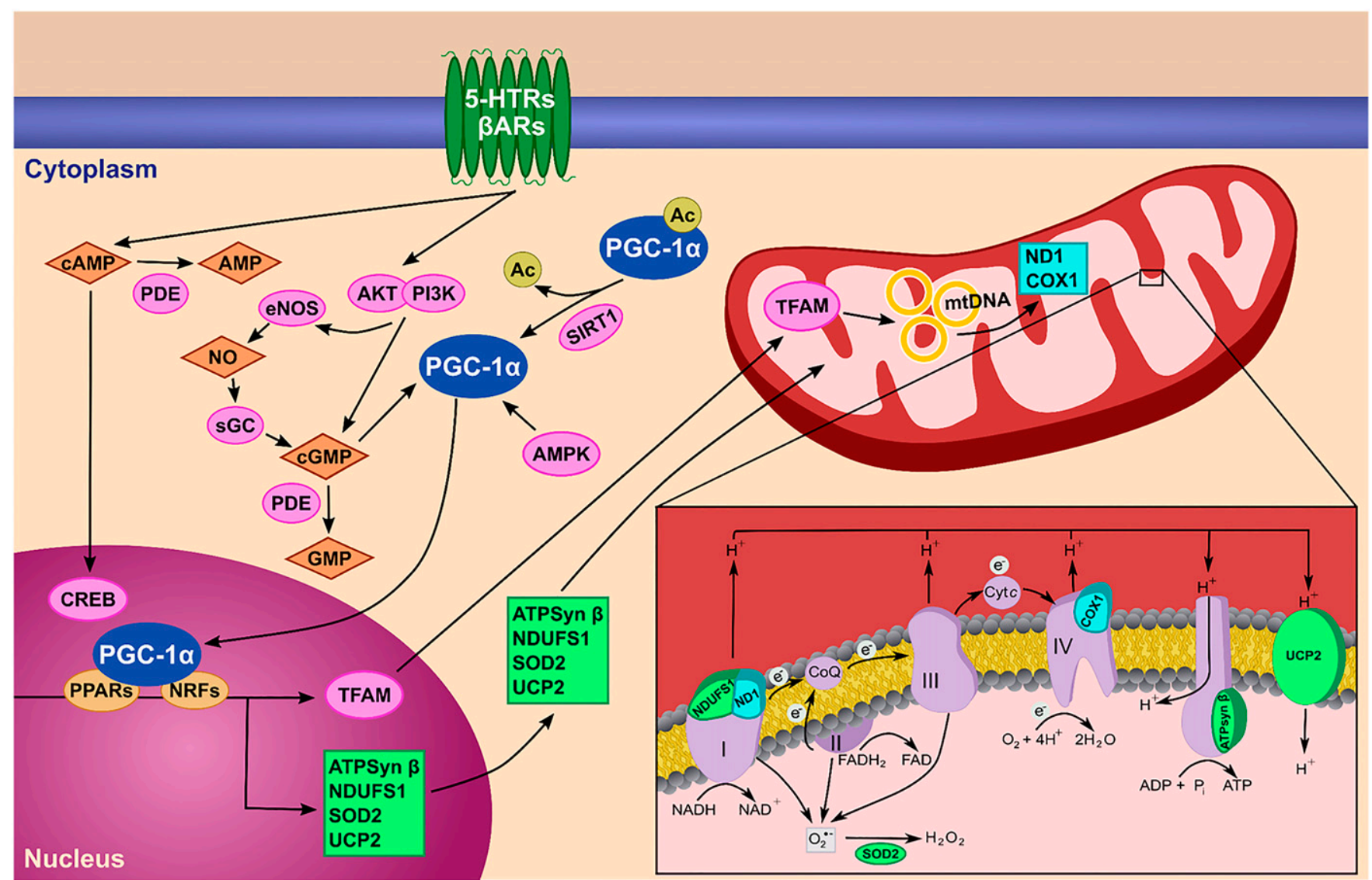

Fig. 3. Regulation of MB. MB is a highly regulated cellular process that involves an array of diverse pathways. Various pharmacological agents can augment MB by targeting different aspects of these pathways, including agonism of G protein-coupled receptors, increased AMPK and cGMP, enhanced SIRT1-mediated PGC- $1 \alpha$ deacetylation, and activation of coactivators that interact with PGC- $1 \alpha$, all culminating in increased expression of mitochondrial genes and ultimately MB. 5-HTR, 5-hydroxytryptamine receptor; Ac, acetyl group; AKT, protein kinase B; AMPK, adenosine monophosphate-activated kinase; ATPSyn $\beta$, ATP synthase $\beta$; $\beta$ AR, $\beta$ adrenergic receptor; CoQ, coenzyme Q; COX1, cytochrome $c$ oxidase subunit 1 ; CREB, cAMP response element binding; Cyt $c$, cytochrome $c$; $\mathrm{e}^{-}$, electron; eNOS, endothelial nitric oxide synthase; mtDNA,: mitochondrial DNA; NAC, $N$-acetylcysteine; ND1,: NADH dehydrogenase subunit 1;, NDUFS1, NADH:ubiquinone oxidoreductase subunit 1; NO, nitric oxide; NRF, nuclear respiratory factor; $\mathrm{O}_{2}^{-}$, superoxide; $\mathrm{PDE}$, phosphodiesterase; $\mathrm{P}_{\mathrm{i}}$, inorganic phosphate; PI3K, phosphoinositide-3 kinase; PPAR, peroxisome proliferator-activated receptor; sGC, soluble guanylate cyclase; SIRT1, sirtuin 1; SOD2, superoxide dismutase 2; UCP2, uncoupling protein 2.

protein kinase B/endothelial nitric oxide synthase/cGMP pathway (Wills et al., 2012; Garrett et al., 2014), enhancing MB. In addition, nitric oxide donors can stimulate cGMP activation and phosphodiesterase inhibitors can prevent the hydrolyzation of cGMP and cAMP (Cameron et al., 2016; Whitaker et al., 2016). Furthermore, resveratrol (a polyphenol that stimulates MB through activation of sirtuin 1, which catalyzes deacetylation of PGC- $1 \alpha$ ) is currently being investigated for the treatment of various neurodegenerative disorders, including Alzheimer and Huntington diseases (Kim et al., 2007; Ho et al., 2010). Although distinct, these pathways all converge on activation of PGC- $1 \alpha$, leading to increased MB (Fujisawa et al., 2009; Dumont et al., 2012). Fortunately, multiple pharmacological agents that induce MB are already approved by the U.S. Food and Drug Administration for the treatment of various pathologies (Table 1). Therefore, attaining approval for the use of these drugs for the treatment of SCI could be an expeditious process.

MB and SCI. Multiple diseases and injuries, including those of the CNS, are accompanied by mitochondrial dysfunction, often including diminished MB. For example, Alzheimer, Parkinson, and Huntington diseases are all characterized by decreased PGC- $1 \alpha$, decreased expression of oxidative phosphorylation proteins, and, in many cases, decreased MB (Hirai et al., 2001; Chaturvedi et al., 2009; Kim et al., 2010; Coskun et al., 2012). Furthermore, ischemic injury, such as that which occurs with SCI, is also followed by reduced oxidative phosphorylation proteins as well as decreased PGC- $1 \alpha$ and TFAM (Whitaker et al., 2016). Given this dysfunction and loss of mitochondrial proteins, interest in pharmacological enhancement of MB (and subsequently, mitochondrial gene expression) for the treatment of numerous disorders has grown. For reviews on MB for the treatment of various diseases, including pathologies of the CNS, see Whitaker et al. (2016) and Cameron et al. (2016).

Currently, no studies have investigated the effect of pharmacological activation of MB on functional recovery after SCI, although published data suggest potential therapeutic efficacy. Hu et al. $(2015,2016)$ recently reported that not only is PGC- $1 \alpha$ expression decreased in the spinal cord after contusive SCI in rats, but spinal lentiviral overexpression of PGC-1 $\alpha$ immediately after injury also attenuates neuronal cell death and promotes functional recovery, which suggests the potential benefit of pharmacologically increasing PGC- $1 \alpha$ and MB after injury. In support of this idea, treatment of mice subjected to renal ischemia/reperfusion with mitochondrial biogenic compounds 24 hours after insult, when injury was 
TABLE 1

Partial list of FDA-approved mitochondrially biogenic agents

\begin{tabular}{|c|c|c|c|}
\hline Drug & Approved to Treat & Mechanism & MB References \\
\hline Atomoxetine & $\mathrm{ADHD}$ & SNRI & $\begin{array}{l}\text { Jesinkey et al. } \\
\quad(2014 \mathrm{~b})\end{array}$ \\
\hline Cilostazol & Claudication & PDE4 inhibitor & Chen et al. (2016) \\
\hline Fluoxetine & MDD, OCD & SSRI & $\begin{array}{l}\text { da Silva et al. } \\
\text { (2015) }\end{array}$ \\
\hline Formoterol & COPD, asthma & $\beta_{2} \mathrm{AR}$ agonist & Wills et al. (2012) \\
\hline Metformin & Type 2 diabetes & $\begin{array}{l}\text { AMPK } \\
\text { activator }\end{array}$ & $\begin{array}{l}\text { Kristensen et al. } \\
\text { (2013) }\end{array}$ \\
\hline Metoprolol & Hypertension & $\beta_{1}$-AR blocker & $\begin{array}{l}\text { Sharma et al. } \\
\text { (2008) }\end{array}$ \\
\hline Riociguat & $\begin{array}{l}\text { Pulmonary } \\
\text { hypertension }\end{array}$ & sGC stimulator & $\begin{array}{l}\text { Cameron et al. } \\
\quad(2016)\end{array}$ \\
\hline Rosiglitazone & Type 2 diabetes & $\operatorname{PPAR} \gamma$ agonist & Strum et al. (2007) \\
\hline Sildenafil & $\begin{array}{l}\text { Erectile } \\
\quad \text { dysfunction }\end{array}$ & PDE5 inhibitor & $\begin{array}{l}\text { Whitaker et al. } \\
\text { (2013) }\end{array}$ \\
\hline
\end{tabular}

ADHD, attention-deficit/hyperactive disorder; AMPK, adenosine monophosphateactivated kinase; AR, adrenergic receptor; COPD, chronic obstructive pulmonary disease; FDA, U.S. Food and Drug Administration; MDD, major depressive disorder OCD, obsessive-compulsive disorder; PDE, phosphodiesterase; PPAR, peroxisome proliferator-activated receptor; sGC, soluble guanylate cyclase; SNRI, serotonin and norepinephrine reuptake inhibitor; SSRI, selective serotonin reuptake inhibitor.

maximal, increased PGC- $1 \alpha$ expression and restored mitochondrial and renal function (Garrett et al., 2014; Jesinkey et al., 2014a). These data indicate the need for further exploration of the therapeutic efficacy of pharmacologically augmenting MB after SCI.

Studies have also demonstrated a positive correlation between PGC- $1 \alpha$ and angiogenesis (Arany et al., 2008; Chinsomboon et al., 2009; Saint-Geniez et al., 2013), a necessary occurrence for effective treatment of SCI pathology. Therefore, therapeutics targeting reestablishment of mitochondrial homeostasis through increased $\mathrm{MB}$ represent a hitherto unexploited mechanism for alleviating several facets of secondary injury progression and improving functional and vascular recovery as well as neuronal survival after SCI.

\section{Conclusions}

Targeting mitochondria for the treatment of SCI is not a novel idea. Mitochondrial dysfunction is a well characterized consequence of secondary injury after SCI and many promising experimental therapeutics enhance mitochondrial function, although generally through prevention via pretreatment or decreased injury through early administration after insult. Unfortunately, many of these agents remain to be assessed in humans. Of the agents that have been assessed, none have yet proven successful for the treatment of SCI. A plausible explanation for this is that in general, these compounds target singular facets of mitochondrial dysfunction, which may not be enough to successfully improve patient outcome. Alternative approaches enhancing several, if not all, aspects of mitochondrial function could prove more efficacious in accelerating recovery of SCI function. Combinatorial therapies, such as pharmacologically increasing antioxidant activity and decreasing mitochondrial fission simultaneously, could address multiple aspects of mitochondrial dysfunction after SCI. Such strategies, however, would undoubtedly require a great deal of refinement and consideration of multiple factors, including drug-drug interactions. Conversely, pharmacological augmentation of
MB has the potential to more efficiently address this deficit. Therefore, the efficacy of mitochondrial biogenic compounds should be investigated for the therapeutic treatment of SCI.

\section{Authorship Contributions}

Wrote or contributed to the writing of the manuscript: Scholpa, Schnellmann.

\section{References}

Adibhatla RM and Hatcher JF (2010) Lipid oxidation and peroxidation in CNS health and disease: from molecular mechanisms to therapeutic opportunities. Antioxid Redox Signal 12:125-169.

Ahmad M, Zakaria A, and Almutairi KM (2016) Effectiveness of minocycline and FK506 alone and in combination on enhanced behavioral and biochemical recovery from spinal cord injury in rats. Pharmacol Biochem Behav 145:45-54.

Al Jadid MS, Robert A, and Al-Mubarak S (2009) The efficacy of alpha-tocopherol in functional recovery of spinal cord injured rats: an experimental study. Spinal Cord 47:662-667.

Anderson DK and Hall ED (1993) Pathophysiology of spinal cord trauma. Ann Emerg Med 22:987-992.

Anderson DK, Means ED, Waters TR, and Green ES (1982) Microvascular perfusion and metabolism in injured spinal cord after methylprednisolone treatment. $J$ Neurosurg 56:106-113.

Anderson DK, Waters TR, and Means ED (1988) Pretreatment with alpha tocopherol enhances neurologic recovery after experimental spinal cord compression injury. J Neurotrauma 5:61-67.

Anwar MA, Al Shehabi TS, and Eid AH (2016) Inflammogenesis of secondary spinal cord injury. Front Cell Neurosci 10:98.

Arany Z, Foo SY, Ma Y, Ruas J, Bommi-Reddy A, Girnun G, Cooper M, Laznik D, Chinsomboon J, Rangwala SM, et al. (2008) HIF-independent regulation of VEGF and angiogenesis by the transcriptional coactivator PGC-1alpha. Nature 451:1008-1012.

Aras M, Altas M, Motor S, Dokuyucu R, Yilmaz A, Ozgiray E, Seraslan Y, and Yilmaz N (2015) Protective effects of minocycline on experimental spinal cord injury in rats. Injury 46:1471-1474.

Bains M and Hall ED (2012) Antioxidant therapies in traumatic brain and spinal cord injury. Biochim Biophys Acta 1822:675-684.

Bao F and Liu D (2004) Hydroxyl radicals generated in the rat spinal cord at the level produced by impact injury induce cell death by necrosis and apoptosis: protection by a metalloporphyrin. Neuroscience 126:285-295.

Baptiste DC and Fehlings MG (2006) Pharmacological approaches to repair the injured spinal cord. J Neurotrauma 23:318-334.

Basso E, Fante L, Fowlkes J, Petronilli V, Forte MA, and Bernardi P (2005) Properties of the permeability transition pore in mitochondria devoid of Cyclophilin D. $J$ Biol Chem 280:18558-18561.

Beattie MS, Hermann GE, Rogers RC, and Bresnahan JC (2002) Cell death in models of spinal cord injury. Prog Brain Res 137:37-47.

Bezprozvanny I (2009) Calcium signaling and neurodegenerative diseases. Trends Mol Med 15:89-100.

Bozbuğa M, Izgi N, and Canbolat A (1998) The effects of chronic alpha-tocopherol administration on lipid peroxidation in an experimental model of acute spinal cord injury. Neurosurg Rev 21:36-42.

Bracken MB, Collins WF, Freeman DF, Shepard MJ, Wagner FW, Silten RM, Hellenbrand KG, Ransohoff J, Hunt WE, Perot PL, Jr, et al. (1984) Efficacy of methylprednisolone in acute spinal cord injury. JAMA 251:45-52.

Bracken MB and Holford TR (1993) Effects of timing of methylprednisolone or naloxone administration on recovery of segmental and long-tract neurological function in NASCIS 2. $J$ Neurosurg 79:500-507.

Bracken MB, Shepard MJ, Collins WF, Jr, Holford TR, Baskin DS, Eisenberg HM Flamm E, Leo-Summers L, Maroon JC, Marshall LF, et al. (1992) Methylprednisolone or naloxone treatment after acute spinal cord injury: 1-year follow-up data. Results of the second national acute spinal cord injury study. $J$ Neurosurg $\mathbf{7 6}$ : 23-31.

Bracken MB, Shepard MJ, Collins WF, Holford TR, Young W, Baskin DS, Eisenberg HM, Flamm E, Leo-Summers L, Maroon J, et al. (1990) A randomized, controlled trial of methylprednisolone or naloxone in the treatment of acute spinal-cord injury. Results of the second National Acute Spinal Cord Injury Study. N Engl J Med 322:1405-1411.

Bracken MB, Shepard MJ, Hellenbrand KG, Collins WF, Leo LS, Freeman DF, Wagner FC, Flamm ES, Eisenberg HM, Goodman JH, et al. (1985) Methylprednisolone and neurological function 1 year after spinal cord injury. Results of the National Acute Spinal Cord Injury Study. J Neurosurg 63:704-713.

Bracken MB, Shepard MJ, Holford TR, Leo-Summers L, Aldrich EF, Fazl M, Fehlings M, Herr DL, Hitchon PW, Marshall LF, et al. (1997) Administration of methylprednisolone for 24 or 48 hours or tirilazad mesylate for 48 hours in the treatment of acute spinal cord injury. Results of the third National Acute Spinal Cord Injury Randomized Controlled Trial. National Acute Spinal Cord Injury Study. JAMA 277:1597-1604

Bracken MB, Shepard MJ, Holford TR, Leo-Summers L, Aldrich EF, Fazl M, Fehlings MG, Herr DL, Hitchon PW, Marshall LF, et al. (1998) Methylprednisolone or tirilazad mesylate administration after acute spinal cord injury: 1-year follow up. Results of the third National Acute Spinal Cord Injury randomized controlled trial. J Neurosurg 89:699-706.

Braughler JM, Chase RL, Neff GL, Yonkers PA, Day JS, Hall ED, Sethy VH, and Lahti RA (1988) A new 21-aminosteroid antioxidant lacking glucocorticoid activity stimulates adrenocorticotropin secretion and blocks arachidonic acid release from mouse pituitary tumor (AtT-20) cells. J Pharmacol Exp Ther 244: $423-427$. 
Bringold U, Ghafourifar P, and Richter C (2000) Peroxynitrite formed by mitochondrial NO synthase promotes mitochondrial $\mathrm{Ca}^{2+}$ release. Free Radic Biol Med 29 : $343-348$

Cameron RB, Beeson CC, and Schnellmann RG (2016) Development of therapeutics that induce mitochondrial biogenesis for the treatment of acute and chronic degenerative diseases. J Med Chem 59:10411-10434.

Candas D and Li JJ (2014) MnSOD in oxidative stress response-potential regulation via mitochondrial protein influx. Antioxid Redox Signal 20:1599-1617.

Cao Y, Lv G, Wang YS, Fan ZK, Bi YL, Zhao L, and Guo ZP (2013) Mitochondrial fusion and fission after spinal sacord injury in rats. Brain Res 1522:59-66.

Caramelo C, Alvarez-Arroyo MV, Yagüe S, Suzuki Y, Castilla MA, Velasco L, Gonzalez-Pacheco FR, and Tejedor A (2004) Cyclosporin A toxicity, and more: vascular endothelial growth factor (VEGF) steps forward. Nephrol Dial Transplant 19:285-288.

Casha S, Zygun D, McGowan MD, Bains I, Yong VW, and Hurlbert RJ (2012) Results of a phase II placebo-controlled randomized trial of minocycline in acute spinal cord injury. Brain 135:1224-1236.

Chaturvedi RK, Adhihetty P, Shukla S, Hennessy T, Calingasan N, Yang L, Starkov A, Kiaei M, Cannella M, Sassone J, et al. (2009) Impaired PGC- $1 \alpha$ function in muscle in Huntington's disease. Hum Mol Genet 18:3048-3065.

Chen Y, Pandiri I, Joe Y, Kim HJ, Kim SK, Park J, Ryu J, Cho GJ, Park JW, Ryter SW, et al. (2016) Synergistic effects of cilostazol and probucol on ER stress-induced hepatic steatosis via heme oxygenase-1-dependent activation of mitochondrial biogenesis. Oxid Med Cell Longev 2016:3949813.

Chinsomboon J, Ruas J, Gupta RK, Thom R, Shoag J, Rowe GC, Sawada N, Raghuram S, and Arany Z (2009) The transcriptional coactivator PGC-1alpha mediates exercise-induced angiogenesis in skeletal muscle. Proc Natl Acad Sci USA 106:21401-21406.

Choi DW and Rothman SM (1990) The role of glutamate neurotoxicity in hypoxicischemic neuronal death. Annu Rev Neurosci 13:171-182.

Coleman WP, Benzel D, Cahill DW, Ducker T, Geisler F, Green B, Gropper MR, Goffin J, Madsen PW, 3rd, Maiman DJ, et al. (2000) A critical appraisal of the reporting of the National Acute Spinal Cord Injury Studies (II and III) of methylprednisolone in acute spinal cord injury. J Spinal Disord 13:185-199.

Coskun P, Wyrembak J, Schriner SE, Chen HW, Marciniack C, Laferla F, and Wallace DC (2012) A mitochondrial etiology of Alzheimer and Parkinson disease. Biochim Biophys Acta 1820:553-564.

Coumans JV, Lin TT, Dai HN, MacArthur L, McAtee M, Nash C, and Bregman BS (2001) Axonal regeneration and functional recovery after complete spinal cord transection in rats by delayed treatment with transplants and neurotrophins. J Neurosci 21:9334-9344.

Crompton M (1999) The mitochondrial permeability transition pore and its role in cell death. Biochem $J$ 341:233-249.

Cui M, Ding H, Chen F, Zhao Y, Yang Q, and Dong Q (2016) Mdivi-1 protects against ischemic brain injury via elevating extracellular adenosine in a cAMP/CREB CD39-dependent manner. Mol Neurobiol 53:240-253.

da Silva AI, Braz GR, Silva-Filho R, Pedroza AA, Ferreira DS, Manhaes de Castro R, and Lagranha $\mathrm{C}$ (2015) Effect of fluoxetine treatment on mitochondrial bioenergetics in central and peripheral rat tissues. Appl Physiol Nutr Metab 40:565-574.

Demediuk P, Lemke M, and Faden AI (1990) Spinal cord edema and changes in tissue content of $\mathrm{Na}^{+}, \mathrm{K}^{+}$, and $\mathrm{Mg}^{2+}$ after impact trauma in rats. Adv Neurol $\mathbf{5 2}$ : 225-232.

Devivo MJ (2012) Epidemiology of traumatic spinal cord injury: trends and future implications. Spinal Cord 50:365-372.

Ding M, Dong Q, Liu Z, Liu Z, Qu Y, Li X, Huo C, Jia X, Fu F, and Wang X (2017) Inhibition of dynamin-related protein 1 protects against myocardial ischemiareperfusion injury in diabetic mice. Cardiovasc Diabetol 16:19.

Dubinsky JM (2005) CNS mitochondria in neurodegenerative disorders. Antioxid Redox Signal 7:1089-1091.

Dumont M, Stack C, Elipenahli C, Jainuddin S, Gerges M, Starkova N, Calingasan NY, Yang L, Tampellini D, Starkov AA, et al. (2012) Bezafibrate administration improves behavioral deficits and tau pathology in P301S mice. Hum Mol Genet 21: $5091-5105$

Evaniew N, Noonan VK, Fallah N, Kwon BK, Rivers CS, Ahn H, Bailey CS, Christie SD, Fourney DR, Hurlbert RJ, et al.; RHSCIR Network (2015) Methylprednisolone for the treatment of patients with acute spinal cord injuries: a propensity scorematched cohort study from a Canadian multi-center spinal cord injury registry. J Neurotrauma 32:1674-1683.

Fouad K, Schnell L, Bunge MB, Schwab ME, Liebscher T, and Pearse DD (2005) Combining Schwann cell bridges and olfactory-ensheathing glia grafts with chondroitinase promotes locomotor recovery after complete transection of the spinal cord. $J$ Neurosci 25:1169-1178.

Friberg H and Wieloch T (2002) Mitochondrial permeability transition in acute neurodegeneration. Biochimie 84:241-250.

Fujisawa K, Nishikawa T, Kukidome D, Imoto K, Yamashiro T, Motoshima H, Matsumura T, and Araki E (2009) TZDs reduce mitochondrial ROS production and enhance mitochondrial biogenesis. Biochem Biophys Res Commun 379:43-48.

Garrett SM, Whitaker RM, Beeson CC, and Schnellmann RG (2014) Agonism of the 5-hydroxytryptamine $1 \mathrm{~F}$ receptor promotes mitochondrial biogenesis and recovery from acute kidney injury. J Pharmacol Exp Ther 350:257-264.

Graumann U, Ritz MF, and Hausmann O (2011) Necessity for re-vascularization after spinal cord injury and the search for potential therapeutic options. Curr Neurovasc Res 8:334-341.

Hall ED (2011) Antioxidant therapies for acute spinal cord injury. Neurotherapeutics 8:152-167.

Hall ED and Braughler JM (1981) Acute effects of intravenous glucocorticoid pretreatment on the in vitro peroxidation of cat spinal cord tissue. Exp Neurol 73:321-324.

Hall ED, McCall JM, and Means ED (1994) Therapeutic potential of the lazaroids (21-aminosteroids) in acute central nervous system trauma, ischemia and subarachnoid hemorrhage. Adv Pharmacol 28:221-268.
Hall ED and Springer JE (2004) Neuroprotection and acute spinal cord injury: a reappraisal. NeuroRx 1:80-100.

Hall ED and Sullivan PG (2005) Preserving function in acute nervous system injury, in From Neuroscience to Neurology: Neuroscience, Molecular Medicine, and the Theraputic Translation of Neurology (Waxman S ed) pp 35-59, Elsevier/Academic Press, San Diego.

Hall ED, Wang JA, Bosken JM, and Singh IN (2016) Lipid peroxidation in brain or spinal cord mitochondria after injury. J Bioenerg Biomembr 48:169-174.

Hall ED, Wolf DL, and Braughler JM (1984) Effects of a single large dose of methylprednisolone sodium succinate on experimental posttraumatic spinal cord ischemia. Dose-response and time-action analysis. J Neurosurg 61:124-130.

Hirai K, Aliev G, Nunomura A, Fujioka H, Russell RL, Atwood CS, Johnson AB, Kress Y, Vinters HV, Tabaton M, et al. (2001) Mitochondrial abnormalities in Alzheimer's disease. J Neurosci 21:3017-3023.

Hirsch T, Susin SA, Marzo I, Marchetti P, Zamzami N, and Kroemer G (1998) Mitochondrial permeability transition in apoptosis and necrosis. Cell Biol Toxicol 14:141-145.

Ho DJ, Calingasan NY, Wille E, Dumont M, and Beal MF (2010) Resveratrol protects against peripheral deficits in a mouse model of Huntington's disease. Exp Neurol 225:74-84.

Hu J, Lang Y, Cao Y, Zhang T, and Lu H (2015) The neuroprotective effect of tetramethylpyrazine against contusive spinal cord injury by activating PGC-1 $\alpha$ in rats. Neurochem Res 40:1393-1401.

Hu J, Lang Y, Zhang T, Ni S, and Lu H (2016) Lentivirus-mediated PGC-1 $\alpha$ overexpression protects against traumatic spinal cord injury in rats. Neuroscience 328: $40-49$

Hurlbert RJ (2000) Methylprednisolone for acute spinal cord injury: an inappropriate standard of care. J Neurosurg 93 (Suppl):1-7.

Ibarra A, Correa D, Willms K, Merchant MT, Guizar-Sahagún G, Grijalva I, and Madrazo I (2003) Effects of cyclosporin-A on immune response, tissue protection and motor function of rats subjected to spinal cord injury. Brain Res $\mathbf{9 7 9}$ $165-178$.

Ibarra A, Guízar-Sahagún G, Correa D, Kretschmer R, Grijalva I, Flores-Murrieta FJ, Castañeda-Hernández G, Odor A, López RM, Franco-Bourland R, et al. (1996a) Alteration of cyclosporin-A pharmacokinetics after experimental spinal cord injury. J Neurotrauma 13:267-272.

Ibarra A, Reyes J, Martínez S, Correa D, Guízar-Sahagún G, Grijalva I, CastañedaHernández G, Flores-Murrieta FJ, Franco-Bourland R, and Madrazo I (1996b) Use of cyclosporin-A in experimental spinal cord injury: design of a dosing strategy to maintain therapeutic levels. $J$ Neurotrauma 13:569-572.

Jesinkey SR, Funk JA, Stallons LJ, Wills LP, Megyesi JK, Beeson CC, and Schnellmann RG (2014a) Formoterol restores mitochondrial and renal function after ischemia-reperfusion injury. J Am Soc Nephrol 25:1157-1162.

Jesinkey SR, Korrapati MC, Rasbach KA, Beeson CC, and Schnellmann RG (2014b) Atomoxetine prevents dexamethasone-induced skeletal muscle atrophy in mice. J Pharmacol Exp Ther 351:663-673.

Jia ZQ, Li G, Zhang ZY, Li HT, Wang JQ, Fan ZK, and Lv G (2016) Time representation of mitochondrial morphology and function after acute spinal cord injury. Neural Regen Res 11:137-143.

Karalija A, Novikova LN, Kingham PJ, Wiberg M, and Novikov LN (2012) Neuroprotective effects of $\mathrm{N}$-acetyl-cysteine and acetyl-L-carnitine after spinal cord injury in adult rats. PLoS One 7:e41086.

Kelly DP and Scarpulla RC (2004) Transcriptional regulatory circuits controlling mitochondrial biogenesis and function. Genes Dev 18:357-368.

Kim D, Nguyen MD, Dobbin MM, Fischer A, Sananbenesi F, Rodgers JT, Delalle I, Baur JA, Sui G, Armour SM, et al. (2007) SIRT1 deacetylase protects against neurodegeneration in models for Alzheimer's disease and amyotrophic lateral sclerosis. EMBO J 26:3169-3179.

Kim J, Moody JP, Edgerly CK, Bordiuk OL, Cormier K, Smith K, Beal MF, and Ferrante RJ (2010) Mitochondrial loss, dysfunction and altered dynamics in Huntington's disease. Hum Mol Genet 19:3919-3935.

Kim SY, Shim MS, Kim KY, Weinreb RN, Wheeler LA, and Ju WK (2014) Inhibition of cyclophilin D by cyclosporin A promotes retinal ganglion cell survival by preventing mitochondrial alteration in ischemic injury. Cell Death Dis 5:e1105.

Kinnally KW, Peixoto PM, Ryu SY, and Dejean LM (2011) Is mPTP the gatekeeper for necrosis, apoptosis, or both? Biochim Biophys Acta 1813:616-622.

Kristensen JM, Larsen S, Helge JW, Dela F, and Wojtaszewski JFP (2013) Two weeks of metformin treatment enhances mitochondrial respiration in skeletal muscle of AMPK kinase dead but not wild type mice. PLoS One 8:e53533.

Kundi S, Bicknell R, and Ahmed Z (2013) The role of angiogenic and wound-healing factors after spinal cord injury in mammals. Neurosci Res 76:1-9.

Lemasters JJ and Holmuhamedov E (2006) Voltage-dependent anion channel (VDAC) as mitochondrial governator-thinking outside the box. Biochim Biophys Acta 1762:181-190.

Lemasters JJ, Nieminen AL, Qian T, Trost LC, Elmore SP, Nishimura Y, Crowe RA Cascio WE, Bradham CA, Brenner DA, et al. (1998) The mitochondrial permeability transition in cell death: a common mechanism in necrosis, apoptosis and autophagy. Biochim Biophys Acta 1366:177-196.

Lewén A and Hillered L (1998) Involvement of reactive oxygen species in membrane phospholipid breakdown and energy perturbation after traumatic brain injury in the rat. J Neurotrauma 15:521-530.

Li G, Jia Z, Cao Y, Wang Y, Li H, Zhang Z, Bi J, Lv G, and Fan Z (2015) Mitochondrial division inhibitor 1 ameliorates mitochondrial injury, apoptosis, and motor dysfunction after acute spinal cord injury in rats. Neurochem Res 40:1379-1392.

Liu D, Sybert TE, Qian H, and Liu J (1998) Superoxide production after spinal injury detected by microperfusion of cytochrome c. Free Radic Biol Med 25:298-304.

Liu JB, Tang TS, and Xiao DS (2004) Changes of free iron contents and its correlation with lipid peroxidation after experimental spinal cord injury. Chin J Traumatol 7 $229-232$

Liu JM, Yi Z, Liu SZ, Chang JH, Dang XB, Li QY, and Zhang YL (2015) The mitochondrial division inhibitor mdivi-1 attenuates spinal cord ischemia-reperfusion 
injury both in vitro and in vivo: Involvement of BK channels. Brain Res 1619: $155-165$

Liu XZ, Xu XM, Hu R, Du C, Zhang SX, McDonald JW, Dong HX, Wu YJ, Fan GS, Jacquin MF, et al. (1997) Neuronal and glial apoptosis after traumatic spinal cord injury. J Neurosci 17:5395-5406.

LoPachin RM, Gaughan CL, Lehning EJ, Kaneko Y, Kelly TM, and Blight A (1999) Experimental spinal cord injury: spatiotemporal characterization of elemental concentrations and water contents in axons and neuroglia. J Neurophysiol 82:2143-2153.

Luo G, Yi J, Ma C, Xiao Y, Yi F, Yu T, and Zhou J (2013) Defective mitochondrial dynamics is an early event in skeletal muscle of an amyotrophic lateral sclerosis mouse model. PLoS One 8:e82112.

Matsumoto S, Friberg H, Ferrand-Drake M, and Wieloch T (1999) Blockade of the mitochondrial permeability transition pore diminishes infarct size in the rat after transient middle cerebral artery occlusion. J Cereb Blood Flow Metab 19:736-741.

Maurer IC, Schippel P, and Volz HP (2009) Lithium-induced enhancement of mitochondrial oxidative phosphorylation in human brain tissue. Bipolar Disord 11: $515-522$.

Mbye LH, Singh IN, Carrico KM, Saatman KE, and Hall ED (2009) Comparative neuroprotective effects of cyclosporin A and NIM811, a nonimmunosuppressive cyclosporin A analog, following traumatic brain injury. J Cereb Blood Flow Metab 29:87-97.

Mbye LH, Singh IN, Sullivan PG, Springer JE, and Hall ED (2008) Attenuation of acute mitochondrial dysfunction after traumatic brain injury in mice by NIM811, a non-immunosuppressive cyclosporin A analog. Exp Neurol 209:243-253.

McEwen ML, Sullivan PG, Rabchevsky AG, and Springer JE (2011) Targeting mitochondrial function for the treatment of acute spinal cord injury. Neurotherapeutics 8:168-179.

McEwen ML, Sullivan PG, and Springer JE (2007) Pretreatment with the cyclosporin derivative, NIM811, improves the function of synaptic mitochondria following spinal cord contusion in rats. J Neurotrauma 24:613-624.

McIntosh LJ and Sapolsky RM (1996) Glucocorticoids may enhance oxygen radicalmediated neurotoxicity. Neurotoxicology 17:873-882.

McMahon SS, Albermann S, Rooney GE, Moran C, Hynes J, Garcia Y, Dockery P O'Brien T, Windebank AJ, and Barry FP (2009) Effect of cyclosporin A on functional recovery in the spinal cord following contusion injury. J Anat 215:267-279.

Middleton JW, Dayton A, Walsh J, Rutkowski SB, Leong G, and Duong S (2012) Life expectancy after spinal cord injury: a 50-year study. Spinal Cord 50:803-811.

Miller ER, 3rd, Pastor-Barriuso R, Dalal D, Riemersma RA, Appel LJ, and Guallar E (2005) Meta-analysis: high-dosage vitamin E supplementation may increase allcause mortality. Ann Intern Med 142:37-46.

Morsy MD and Bashir SO (2013) Alpha-tocopherol ameliorates oxidative renal insult associated with spinal cord reperfusion injury. J Physiol Biochem 69:487-496.

Morsy MD, Mostafa OA, and Hassan WN (2010) A potential protective effect of alphatocopherol on vascular complication in spinal cord reperfusion injury in rats. J Biomed Sci 17:55.

Moskowitz MA, Lo EH, and Iadecola C (2010) The science of stroke: mechanisms in search of treatments. Neuron 67:181-198.

Murphy MP (1997) Selective targeting of bioactive compounds to mitochondria. Trends Biotechnol 15:326-330.

Murphy MP (2001) Development of lipophilic cations as therapies for disorders due to mitochondrial dysfunction. Expert Opin Biol Ther 1:753-764.

Murphy MP and Smith RA (2007) Targeting antioxidants to mitochondria by conjugation to lipophilic cations. Annu Rev Pharmacol Toxicol 47:629-656.

Myers J, Lee M, and Kiratli J (2007) Cardiovascular disease in spinal cord injury: an overview of prevalence, risk, evaluation, and management. Am J Phys Med Rehabil 86:142-152.

Norenberg MD and Rao KV (2007) The mitochondrial permeability transition in neurologic disease. Neurochem Int 50:983-997.

Oyinbo CA (2011) Secondary injury mechanisms in traumatic spinal cord injury: a nugget of this multiply cascade. Acta Neurobiol Exp (Warsz) 71:281-299.

Pandya JD, Readnower RD, Patel SP, Yonutas HM, Pauly JR, Goldstein GA Rabchevsky AG, and Sullivan PG (2014) N-acetylcysteine amide confers neuroprotection, improves bioenergetics and behavioral outcome following TBI. Exp Neurol 257:106-113.

Patel SP, Sullivan PG, Lyttle TS, Magnuson DSK, and Rabchevsky AG (2012) AcetylL-carnitine treatment following spinal cord injury improves mitochondrial function correlated with remarkable tissue sparing and functional recovery. Neuroscience 210:296-307.

Patel SP, Sullivan PG, Lyttle TS, and Rabchevsky AG (2010) Acetyl-L-carnitine ameliorates mitochondrial dysfunction following contusion spinal cord injury. $J$ Neurochem 114:291-301.

Patel SP, Sullivan PG, Pandya JD, Goldstein GA, VanRooyen JL, Yonutas HM, Eldahan KC, Morehouse J, Magnuson DS, and Rabchevsky AG (2014) $\mathrm{N}$-acetylcysteine amide preserves mitochondrial bioenergetics and improves functional recovery following spinal trauma. Exp Neurol 257:95-105.

Patel SP, Sullivan PG, Pandya JD, and Rabchevsky AG (2009) Differential effects of the mitochondrial uncoupling agent, 2,4-dinitrophenol, or the nitroxide antioxidant, Tempol, on synaptic or nonsynaptic mitochondria after spinal cord injury. $J$ Neurosci Res 87:130-140.

Pettegrew JW, Levine J, and McClure RJ (2000) Acetyl-L-carnitine physicalchemical, metabolic, and therapeutic properties: relevance for its mode of action in Alzheimer's disease and geriatric depression. Mol Psychiatry 5:616-632.

Pivovarova NB and Andrews SB (2010) Calcium-dependent mitochondrial function and dysfunction in neurons. FEBS $J$ 277:3622-3636.

Puca FM, Genco S, Specchio LM, Brancasi B, D’Ursi R, Prudenzano A, Miccoli A, Scarcia R, Martino R, and Savarese M (1990) Clinical pharmacodynamics of acetyl-Lcarnitine in patients with Parkinson's disease. Int J Clin Pharmacol Res 10:139-143.

Qiao F, Atkinson C, Kindy MS, Shunmugavel A, Morgan BP, Song H, and Tomlinson S (2010) The alternative and terminal pathways of complement mediate posttraumatic spinal cord inflammation and injury. Am J Pathol 177:3061-3070.
Qiao H, Zhang Q, Yuan H, Li Y, Wang D, Wang R, and He X (2015) Elevated neuronal $\alpha$-synuclein promotes microglia activation after spinal cord ischemic/reperfused injury. Neuroreport 26:656-661.

Rabchevsky AG, Fugaccia I, Sullivan PG, and Scheff SW (2001) Cyclosporin A treatment following spinal cord injury to the rat: behavioral effects and stereological assessment of tissue sparing. $J$ Neurotrauma 18:513-522.

Rabchevsky AG, Patel SP, and Springer JE (2011) Pharmacological interventions for spinal cord injury: where do we stand? How might we step forward? Pharmacol Ther 132:15-29.

Ranieri M, Del Bo R, Bordoni A, Ronchi D, Colombo I, Riboldi G, Cosi A, Servida M, Magri F, Moggio M, et al. (2012) Optic atrophy plus phenotype due to mutations in the OPA1 gene: two more Italian families. J Neurol Sci 315:146-149.

Ravikumar R, McEwen ML, and Springer JE (2007) Post-treatment with the cyclosporin derivative, NIM811, reduced indices of cell death and increased the volume of spared tissue in the acute period following spinal cord contusion. $J$ Neurotrauma 24:1618-1630.

Reulen HJ, Hadjidimos A, and Hase U (1973) Steroids in the treatment of brain edema, in Brain Edema/Cerebello Pontine Angle Tumors: Pathophysiology and Therapy/Diagnosis and Surgery (Schürmann K, Brock M, Reulen HJ, and Voth D eds) pp 92-105, Springer, Berlin.

Roberts LJ, 2nd, Oates JA, Linton MF, Fazio S, Meador BP, Gross MD, Shyr Y, and Morrow JD (2007) The relationship between dose of vitamin $\mathrm{E}$ and suppression of oxidative stress in humans. Free Radic Biol Med 43:1388-1393.

Rowland JW, Hawryluk GW, Kwon B, and Fehlings MG (2008) Current status of acute spinal cord injury pathophysiology and emerging therapies: promise on the horizon. Neurosurg Focus 25:E2.

Saint-Geniez M, Jiang A, Abend S, Liu L, Sweigard H, Connor KM, and Arany Z (2013) PGC-1 $\alpha$ regulates normal and pathological angiogenesis in the retina. Am J Pathol 182:255-265.

Sapolsky RM (1985) Glucocorticoid toxicity in the hippocampus: temporal aspects of neuronal vulnerability. Brain Res 359:300-305.

Saraste M (1999) Oxidative phosphorylation at the fin de siècle. Science 283: 1488-1493.

Scheff SW and Sullivan PG (1999) Cyclosporin A significantly ameliorates cortical damage following experimental traumatic brain injury in rodents. J Neurotrauma 16:783-792.

Schenk LK, Rinschen MM, Klokkers J, Kurian SM, Neugebauer U, Salomon DR, Pavenstaedt H, Schlatter E, and Edemir B (2010) Cyclosporin-A induced toxicity in rat renal collecting duct cells: interference with enhanced hypertonicity induced apoptosis. Cell Physiol Biochem 26:887-900.

Scott I and Youle RJ (2010) Mitochondrial fission and fusion. Essays Biochem 47: 85-98.

Sekhon LH and Fehlings MG (2001) Epidemiology, demographics, and pathophysiology of acute spinal cord injury. Spine 26 (Suppl):S2-S12.

Sesso A, Marques MM, Monteiro MM, Schumacher RI, Colquhoun A, Belizário J, Konno SN, Felix TB, Botelho LA, Santos VZ, et al. (2004) Morphology of mitochondrial permeability transition: morphometric volumetry in apoptotic cells. Anat Rec A Discov Mol Cell Evol Biol 281:1337-1351.

Sharma V, Dhillon P, Wambolt R, Parsons H, Brownsey R, Allard MF, and McNeill JH (2008) Metoprolol improves cardiac function and modulates cardiac metabolism in the streptozotocin-diabetic rat. Am J Physiol Heart Circ Physiol 294:H1609-H1620.

Shibuya S, Yamamoto T, and Itano T (2009) Glial and axonal regeneration following spinal cord injury. Cell Adhes Migr 3:99-106.

Short DJ, El Masry WS, and Jones PW (2000) High dose methylprednisolone in the management of acute spinal cord injury - a systematic review from a clinical perspective. Spinal Cord 38:273-286.

Sonmez E, Kabatas S, Ozen O, Karabay G, Turkoglu S, Ogus E, Yilmaz C, Caner H, and Altinors N (2013) Minocycline treatment inhibits lipid peroxidation, preserves spinal cord ultrastructure, and improves functional outcome after traumatic spinal cord injury in the rat. Spine 38:1253-1259.

Springer JE, Rao RR, Lim HR, Cho SI, Moon GJ, Lee HY, Park EJ, Noh JS, and Gwag BJ (2010) The functional and neuroprotective actions of Neu2000, a dual-acting pharmacological agent, in the treatment of acute spinal cord injury. $J$ Neurotrauma 27:139-149.

Starkov AA (2010) The molecular identity of the mitochondrial $\mathrm{Ca}^{2+}$ sequestration system. FEBS J 277:3652-3663.

Strum JC, Shehee R, Virley D, Richardson J, Mattie M, Selley P, Ghosh S, Nock C, Saunders A, and Roses A (2007) Rosiglitazone induces mitochondrial biogenesis in mouse brain. J Alzheimers Dis 11:45-51.

Sullivan PG, Krishnamurthy S, Patel SP, Pandya JD, and Rabchevsky AG (2007) Temporal characterization of mitochondrial bioenergetics after spinal cord injury. $J$ Neurotrauma 24:991-999.

Sullivan PG, Rabchevsky AG, Keller JN, Lovell M, Sodhi A, Hart RP, and Scheff SW (2004a) Intrinsic differences in brain and spinal cord mitochondria: Implication for therapeutic interventions. $J$ Comp Neurol 474:524-534.

Sullivan PG, Springer JE, Hall ED, and Scheff SW (2004b) Mitochondrial uncoupling as a therapeutic target following neuronal injury. J Bioenerg Biomembr 36:353-356.

Sullivan PG, Thompson M, and Scheff SW (2000) Continuous infusion of cyclosporin A postinjury significantly ameliorates cortical damage following traumatic brain injury. Exp Neurol 161:631-637.

Sullivan PG, Thompson MB, and Scheff SW (1999) Cyclosporin A attenuates acute mitochondrial dysfunction following traumatic brain injury. Exp Neurol 160: $226-234$

Szalowska E, Pronk TE, and Peijnenburg AA (2015) Cyclosporin A induced toxicity in mouse liver slices is only slightly aggravated by Fxr-deficiency and co-occurs with upregulation of pro-inflammatory genes and downregulation of genes involved in mitochondrial functions. BMC Genomics 16:822.

Tang WX, Wu WH, Qiu HY, Bo H, and Huang SM (2013) Amelioration of rhabdomyolysis-induced renal mitochondrial injury and apoptosis through suppression of Drp-1 translocation. J Nephrol 26:1073-1082. 
Tanhoffer RA, Yamazaki RK, Nunes EA, Pchevozniki AI, Pchevozniki AM, Nogata C, Aikawa J, Bonatto SJ, Brito G, Lissa MD, et al. (2007) Glutamine concentration and immune response of spinal cord-injured rats. J Spinal Cord Med $\mathbf{3 0}$ 140-146.

Tator CH and Fehlings MG (1991) Review of the secondary injury theory of acute spinal cord trauma with emphasis on vascular mechanisms. J Neurosurg $\mathbf{7 5}$ : $15-26$

Teng YD, Choi H, Onario RC, Zhu S, Desilets FC, Lan S, Woodard EJ, Snyder EY, Eichler ME, and Friedlander RM (2004) Minocycline inhibits contusion-triggered mitochondrial cytochrome c release and mitigates functional deficits after spinal cord injury. Proc Natl Acad Sci USA 101:3071-3076.

Tomassini V, Pozzilli C, Onesti E, Pasqualetti P, Marinelli F, Pisani A, and Fieschi C (2004) Comparison of the effects of acetyl L-carnitine and amantadine for the treatment of fatigue in multiple sclerosis: results of a pilot, randomised, doubleblind, crossover trial. J Neurol Sci 218:103-108.

Totoiu MO and Keirstead HS (2005) Spinal cord injury is accompanied by chronic progressive demyelination. J Comp Neurol 486:373-383.

Turrens JF (2003) Mitochondrial formation of reactive oxygen species. J Physiol 552: 335-344.

Uchino H, Minamikawa-Tachino R, Kristián T, Perkins G, Narazaki M, Siesjö BK, and Shibasaki F (2002) Differential neuroprotection by cyclosporin A and FK506 following ischemia corresponds with differing abilities to inhibit calcineurin and the mitochondrial permeability transition. Neurobiol Dis 10:219-233.

Uttara B, Singh AV, Zamboni P, and Mahajan RT (2009) Oxidative stress and neurodegenerative diseases: a review of upstream and downstream antioxidant therapeutic options. Curr Neuropharmacol 7:65-74

Ventura-Clapier R, Garnier A, and Veksler V (2008) Transcriptional control of mitochondrial biogenesis: the central role of PGC-1alpha. Cardiovasc Res 79:208-217.

Violi F, Marino R, Milite MT, and Loffredo L (1999) Nitric oxide and its role in lipid peroxidation. Diabetes Metab Res Rev 15:283-288.

Visavadiya NP, McEwen ML, Pandya JD, Sullivan PG, Gwag BJ, and Springer JE (2013) Antioxidant properties of Neu2000 on mitochondrial free radicals and oxidative damage. Toxicol In Vitro 27:788-797.

Waldmeier PC, Feldtrauer JJ, Qian T, and Lemasters JJ (2002) Inhibition of the mitochondrial permeability transition by the nonimmunosuppressive cyclosporin derivative NIM811. Mol Pharmacol 62:22-29.

Waldmeier PC, Zimmermann K, Qian T, Tintelnot-Blomley M, and Lemasters JJ (2003) Cyclophilin D as a drug target. Curr Med Chem 10:1485-1506.

Walters BC, Hadley MN, Hurlbert RJ, Aarabi B, Dhall SS, Gelb DE, Harrigan MR, Rozelle CJ, Ryken TC, and Theodore N; American Association of Neurological Surgeons; Congress of Neurological Surgeons (2013) Guidelines for the management of acute cervical spine and spinal cord injuries: 2013 update. Neurosurgery 60 (Suppl 1):82-91.

Wang X and Michaelis EK (2010) Selective neuronal vulnerability to oxidative stress in the brain. Front Aging Neurosci 2:12.

Wells JE, Hurlbert RJ, Fehlings MG, and Yong VW (2003) Neuroprotection by minocycline facilitates significant recovery from spinal cord injury in mice. Brain 126:1628-1637.
Whitaker RM, Corum D, Beeson CC, and Schnellmann RG (2016) Mitochondrial biogenesis as a pharmacological target: a new approach to acute and chronic diseases. Annu Rev Pharmacol Toxicol 56:229-249.

Whitaker RM, Wills LP, Stallons LJ, and Schnellmann RG (2013) cGMP-selective phosphodiesterase inhibitors stimulate mitochondrial biogenesis and promote recovery from acute kidney injury. J Pharmacol Exp Ther 347:626-634.

Wills LP, Trager RE, Beeson GC, Lindsey CC, Peterson YK, Beeson CC, and Schnellmann RG (2012) The $\beta 2$-adrenoceptor agonist formoterol stimulates mitochondrial biogenesis. J Pharmacol Exp Ther 342:106-118.

Wu Q, Xia SX, Li QQ, Gao Y, Shen X, Ma L, Zhang MY, Wang T, Li YS, Wang ZF, et al. (2016) Mitochondrial division inhibitor 1 (Mdivi-1) offers neuroprotection through diminishing cell death and improving functional outcome in a mouse model of traumatic brain injury. Brain Res 1630:134-143.

Wyndaele M and Wyndaele JJ (2006) Incidence, prevalence and epidemiology of spina cord injury: what learns a worldwide literature survey? Spinal Cord 44:523-529.

Xiong Y, Peterson PL, and Lee CP (1999) Effect of N-acetylcysteine on mitochondrial function following traumatic brain injury in rats. $J$ Neurotrauma 16:1067-1082.

Xiong Y, Rabchevsky AG, and Hall ED (2007) Role of peroxynitrite in secondary oxidative damage after spinal cord injury. J Neurochem 100:639-649.

Xiong Y, Singh IN, and Hall ED (2009) Tempol protection of spinal cord mitochondria from peroxynitrite-induced oxidative damage. Free Radic Res 43:604-612.

Yang ML, Li JJ, So KF, Chen JY, Cheng WS, Wu J, Wang ZM, Gao F, and Young W (2012) Efficacy and safety of lithium carbonate treatment of chronic spinal cord injuries: a double-blind, randomized, placebo-controlled clinical trial. Spinal Cord 50:141-146.

Yick LW, So KF Cheung PT, and Wu WT (2004) Lithium chloride reinforces the regeneration-promoting effect of chondroitinase $\mathrm{ABC}$ on rubrospinal neurons after spinal cord injury. J Neurotrauma 21:932-943.

Young W and Flamm ES (1982) Effect of high-dose corticosteroid therapy on blood flow, evoked potentials, and extracellular calcium in experimental spinal injury. $J$ Neurosurg 57:667-673.

Young W and Koreh I (1986) Potassium and calcium changes in injured spinal cords. Brain Res 365:42-53

Zhang N, Wang S, Li Y, Che L, and Zhao Q (2013) A selective inhibitor of Drp1, mdivi-1, acts against cerebral ischemia/reperfusion injury via an anti-apoptotic pathway in rats. Neurosci Lett 535:104-109.

Zhang ZY, Fan ZK, Cao Y, Jia ZQ, Li G, Zhi XD, Yu DS, and Lv G (2015) Acetyl-Lcarnitine ameliorates mitochondrial damage and apoptosis following spinal cord injury in rats. Neurosci Lett 604:18-23.

Züchner S, Mersiyanova IV, Muglia M, Bissar-Tadmouri N, Rochelle J, Dadali EL, Zappia M, Nelis E, Patitucci A, Senderek J, et al. (2004) Mutations in the mitochondrial GTPase mitofusin 2 cause Charcot-Marie-Tooth neuropathy type 2A. Nat Genet 36:449-451.

Address correspondence to: Rick G. Schnellmann, Department of Pharmacology and Toxicology, University of Arizona, 1295 N. Martin, P.O. Box 210202 , Tucson, AZ 85721. E-mail: schnell@pharmacy.arizona.edu 